ORIGINAL ARTICLE

\title{
Evaluation of the Antibody Response against Hepatitis C Virus Infection in Patients on Maintenance Hemodialysis (MHD): A Pilot Study
}

\author{
S Sultana ${ }^{1}$, MK Ali ${ }^{2}$, AK Shaha ${ }^{3}$, NN Khan ${ }^{4}$, MA Husain ${ }^{5}$ \\ ${ }^{1}$ Dept of Microbiology, Delta Medical College, Dhaka \\ ${ }^{2}$ Dept of Paediatrics, Ibn Sina Medical College, Dhaka \\ ${ }^{3}$ Dept of Paediatrics, Sher-E-Bangla Medical College, Barisal \\ ${ }^{4}$ BIRDEM Academy, Dhaka \\ ${ }^{5}$ Dept of Dermatology, Ibn Sina Medical College, Dhaka
}

\begin{abstract}
Majority of the patients with end stage renal disease (ESRD) are on maintenance hemodialysis (MHD) in Bangladesh. Dialysis patients are at high risk for contracting blood borne infection including hepatitis $\mathrm{C}$ virus (HCV) infection. The aim of this study was to evaluate the antibody response of hepatitis $\mathrm{C}$ virus infection in patients on MHD by detecting different viral markers in blood. A total of 88 patients with chronic kidney disease (CKD)were recruited from BIRDEM and BSMMU during the period from June 2006 to June 2007. Of them 63 patients on MHD and 25 predialysis patients were taken as cases and controls respectivly. Anti-HCV antibody were positive in $38 \%$ of dialysis patients but none of the controls were positive for Anti-HCV. When HCV positive MHD patients (38\%) were compared to HCV negative MHD patients $(62 \%)$, it showed that HCV positive patients had longer duration of dialysis $(24 \pm 25$ vs $9 \pm 6$ months, $\mathrm{p}<0.001)$, increased number blood transfusions ( $29 \pm 34$ vs $10 \pm 9$ units, $\mathrm{p}<0.004)$ and elevated serum alanine aminotransferase level $(35 \pm 23$ vs $20 \pm 9 \mathrm{U} / \mathrm{L}$, $\mathrm{p}=0.001)$. Implementing comprehensive infection control program by routine screening of the CKD patients, safe blood transfusion program, reducing transfusion of blood by use of erythropoietin and proper disinfection and cleaning of hemodialysis units may reduce the infection by HCV Virus.
\end{abstract}

Key words: Hepatitis C virus, Antibody response, Hemodialysis

\section{Introduction}

End-stage renal disease (ESRD) subjects on maintenance hemodialysis (MHD) are at high risk for hepatitis $\mathrm{C}$ virus infection ${ }^{1}$. The process of hemodialysis requires vascular access for prolonged period and many patients depend on multiple blood transfusions for correction of anemia ${ }^{2}$.

The prevalence of hepatitis C virus (HCV) infection among ESRD patients on MHD is persistently higher than the general population ${ }^{3}$. Predisposing factors are immunocompromised patients on long-term hemodialysis ${ }^{4}$, older age, black race, diabetes, concomitant hepatitis $\mathrm{B}$ virus (HBV) infection, prior renal transplant and alcohol or drug abuse, human immunodeficiency virus/acquired immune deficiency syndrome

Bangladesh J Med Biochem 2014; 7(1): 9-13
(HIV/AIDS), recurrent cellulitis or gangrene ${ }^{5}$. Risk factors associated with HCV infection among hemodialysis patients include history of blood transfusion, the volume of blood transfused and years on dialysis 6 . Previous blood transfusion, number of hemodialysis centers visited and years on dialysis are the major risk factor independently associated with higher rates of $\mathrm{HCV}$ infection ${ }^{7}$. $\mathrm{HCV}$ accounting for $20 \%-30 \%$ of acute hepatitis, $75 \%-85 \%$ chronic hepatitis ${ }^{8}$. Most hemodialysis patients with newly acquired $\mathrm{HCV}$ infection have elevated serum alanine aminotransferase (ALT) levels ${ }^{2}$. In chronic HCV infection, 60$70 \%$ patients showed persistence of fluctuating ALT elevation, indicating active liver disease ${ }^{9}$. 
Approximately, 170 million world populations have been infected with hepatitis $\mathrm{C}$ virus infection ${ }^{10}$. Seroprevalence of anti-HCV was found to be 4\%-9.93\% in India in two studies $^{11,12}$. In Pakistan $5.31 \%$ were positive for anti-HCV ${ }^{13}$. One study showed that $24.8 \%$ intravenous drug users of Bangladesh were positive for $\mathrm{HCV}$ infection ${ }^{14}$. In Bangladesh, HCV seropositivity among professional blood donors was $1.2 \% 15$. Seropositivity was $6.8 \%$ in type 2 diabetic patients ${ }^{16}$. The prevalence of HCV infection was $7 \%$ in predialysis and $20.2 \%$ of hemodialysis patients in Turkey ${ }^{17}$.

The anti-HCV prevalence was $43 \%, 37.2 \%, 19 \%$, and $16.4 \%$ in hemodialysis patients in China, Brazil, Japan and Hong Kong respectively ${ }^{18,19}$. In another study the prevalence of anti-HCV among hemodialysis patients in different countries were reported as in Netherlands 3.3\%, Italy $29.0 \%$, Tunisia 41.0\%, Egypt $80.0 \%$, Saudi Arabia 68\%, Australia 5.9\%, and Taiwan $60.0 \%^{20}$. In Pakistan and India the prevalence of anti-HCV was $23.7 \%$ and $9.93 \%$ in hemodialysis patients respectively ${ }^{21,22}$. In Bangladesh, $6 \%$ of all patients on MHD were serologically positive for hepatitis $\mathrm{C}$ virus infection shown in an earlier study ${ }^{23}$ but a recent one showed that it has increased to $7.1 \%^{24}$.

There are no study reports on immune status against Hepatitis $\mathrm{C}$ virus (HCV) infections among predialysis and dialysis patients in Bangladesh. Therefore, this study was undertaken to evaluate the antibody status of $\mathrm{HCV}$ in predialysis and dialysis patients followed up in two selected tertiary renal care centers.

\section{Materials and Methods}

This cross sectional study was carried out in the Department of Immunology, BIRDEM, Dhaka and Department of Nephrology BSMMU, during the period from June 2006 to June 2007.

Eighty-eight patients were finally included in this study. Of them 63 end stage renal disease (ESRD) patients who were on maintenance hemodialysis for at least 3 months and getting dialysis through arteriovensous (AV) fistula considered as cases and 25 chronic renal failure patients attending Nephrology out-patient departments of BIRDEM and BSMMU and CRF (chronic renal failure) patients follow-up project who were not on dialysis (predialysis) were considered as control group.

Five $\mathrm{ml}$ of blood was taken from the arterial channel immediately after pricking the fistula during dialysis session in MHD patients and labeled with a known serial number for each patient. In controls fasting samples were taken. Serum sample were preserved at $-20^{\circ} \mathrm{C}$ and assayed within fifteen days of collection.

Serological markers for hepatitis C (Anti-HCV) was performed by commercial third generation enzymelinked immunosorbent assay kit (Origin: Diasorin, Italy). Serum ALT was measured by kinetic method.

All the relevant data were compiled on a master table first and then analysed using software with statistical package for social science (SPSS) version 13. Percentages were calculated to find out proportion of the finding. Results were expressed as mean \pm SD or in percentage where suitable. Level of significance was expressed as $p$ value and $p<0.05$ was considered significant.

\section{Results}

Table I shows that different baseline parameters like age, duration of diabetes (DM Duration), duration of chronic kidney disease (CKD Duration) and related laboratory parameters were similar between cases (MHD patients) and controls (predialysis patients). The only difference was in serum creatinine (S.Cr) level and this was higher in MHD patients $(\mathrm{p}<0.001)$.

Table- I: Baseline Parameters of Study Subjects

\begin{tabular}{lccc}
\hline Parameters & Cases $(\mathrm{n}=63)$ & Controls $(\mathrm{n}=25)$ & $\mathrm{p}$ Value \\
\hline Age (yrs) & $54 \pm 11$ & $57 \pm 10$ & 0.28 \\
M/F & $36 / 27$ & $15 / 10$ & 0.80 \\
DM Duration(yrs) & $12 \pm 6$ & $5 \pm 2$ & 0.92 \\
CKD Duration(yrs) & $6 \pm 4$ & $4 \pm 3$ & 0.53 \\
S. Cr (mg \%) & $9 \pm 2.5$ & $4 \pm 2$ & 0.001 \\
ALT (U/L) & $25 \pm 17$ & $20 \pm 16$ & 0.30
\end{tabular}

M/F- Male /Female; DM- Diabetes Mellitus; CKDChronic Kidney Disease; $S$ Cr-Serum Creatinine; ALTAlanine amino transferase Data are expressed as mean (SD); $p$ value reached from student's $t$ test. 


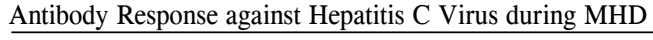

Table- II: Distribution of patients by anti-HCV

\begin{tabular}{|c|c|c|c|c|c|}
\hline \multirow[b]{2}{*}{ Anti } & \multirow[b]{2}{*}{ - $\mathrm{HCV}$} & \multicolumn{2}{|c|}{ Subject } & \multicolumn{2}{|l|}{ Total } \\
\hline & & $\begin{array}{r}\text { Cases } \\
\mathrm{n}=63(\%)\end{array}$ & $\begin{array}{r}\text { Controls } \\
n=25(\%)\end{array}$ & $\mathrm{n}=88(\%)$ & $\mathrm{p}$ value \\
\hline Positi & & $24(38.1)$ & & $24(27.3)$ & 0.001 \\
\hline Negat & & $39(61.9)$ & $25(100)$ & $64(72.7)$ & \\
\hline
\end{tabular}

Anti-HCV - Antibody to hepatitis C virus; $p$ value reached from chi square test.

Table- III: Distribution of MHD Patients by anti-HCV

\begin{tabular}{lccc}
\hline Parameter & $\begin{array}{c}\text { Positive } \\
\mathrm{n}=37(59 \%)\end{array}$ & $\begin{array}{c}\text { Negative } \\
\mathrm{n}=26(41 \%)\end{array}$ & $\mathrm{p}$ Value \\
\hline DM Duration (yrs) & $14 \pm 6$ & $13 \pm 8$ & 0.65 \\
Dialysis Duration (m) & $11 \pm 8$ & $20 \pm 26$ & 0.09 \\
BT (total units) & $11 \pm 10$ & $26 \pm 34$ & $0.02^{*}$ \\
BT (units/month) & $1.1 \pm 1.1$ & $1.6 \pm 1.3$ & 0.05 \\
Dialyzer Reuse & $2 \pm 1$ & $3 \pm 1$ & 0.17 \\
Anti HCV “+ve” & $32 \%$ & $46 \%$ & 0.29 \\
\hline
\end{tabular}

DM- Diabetes Mellitus; BT-Blood Transfusion; ALTAlanine amino transferase Data are expressed as mean (SD); $p$ value reached from student's t test.

Table- IV: Comparisons of dialysis patients according to the use of Erythropoietin

\begin{tabular}{llll}
\hline & $\begin{array}{l}\text { Positive } \\
\mathbf{n = 2 4}(\mathbf{3 8 \%})\end{array}$ & $\begin{array}{l}\text { Negative } \\
\mathbf{n = 3 9}(\mathbf{6 2} \%)\end{array}$ & $\mathbf{p}$ Value \\
\hline DM Duration (yrs) & $12 \pm 6$ & $15 \pm 8$ & 0.14 \\
Dialysis Duration (m) & $24 \pm 25$ & $9 \pm 6$ & 0.001 \\
BT (total units) & $29 \pm 34$ & $10 \pm 9$ & 0.003 \\
Dialyzer Reuse & $3 \pm 1$ & $2 \pm 1$ & 0.24 \\
ALT (U/L) & $35 \pm 23$ & $20 \pm 9$ & 0.001 \\
\hline
\end{tabular}

DM- Diabetes Mellitus; BT-Blood Transfusion; Anti$H C V$ - Antibody to hepatitis $C$ virus

Data are expressed as mean (SD); $P$ value reached from student's $t$ test.

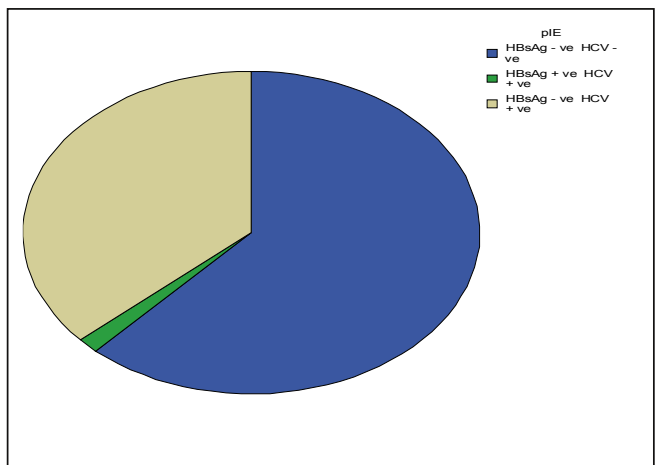

Figure 1: Pie diagram showing prevalence of Hepatitis B virus and Hepatitis $\mathrm{C}$ virus among dialysis (MHD) patients

Result from table II shows a statistically significant difference between cases and controls in terms of anti-HCV $\mathrm{p}<0.001$ indicating that positive antiHCV was high among the cases 38.1(\%). However, no positive cases were found among the controls.

Table III indicateds that the positivity of anti$\mathrm{HCV}$ increases with longer duration of maintenance haemodialysis and higher number of blood transfusions. Also the positive patients had a relatively higher serum level of alanine aminotransferase.

Table IV shows a statistically significant difference in respect of total units of blood transfusion recieved between two groups, indicating that erythropoietin users patients had less blood transfusion (11 \pm 10 units) needed than the negative ones $(26 \pm 34$ units, $p=0.02)$. This table also shows that anti-HCV positivity between two groups was similar.

Figure 1 shows that $36.5 \%$ patients had only HCV infection, $1.6 \%$ patients had both HBV and HCV infection and $61.9 \%$ had none of the infection.

\section{Discussion}

In the present study, anti-HCV positivity was observed to be significantly higher in the hemodialysis patient (38\%) and no positive anti$\mathrm{HCV}$ case was found in CRF patients without dialysis which is in agreement with the study of Lopez-Alcorocho et $\mathrm{al}^{25}$. Some authors reported lower anti-HCV positivity (4.4\%) in CRF patients 
on hemodialysis when compared with CRF patients without dialysis $(17.1 \%)^{26}$. Another study observerd similar prevalence of anti-HCV (7\%) among CRF patients on hemodialysis. A high positivity was also reported in Sudanese patients on hemodialysis $(23.7 \%)^{27}$. These differences in observations among dialysis subjects could be related partly to screening protocols and the sensitivity of the tests employed. Higher prevalence of anti-HCV in MHD subjects may be due to the fact that dialysis units of the two institutions involved in this study have not been using separate dialysis machine for known anti-HCV positive cases. Again higher number of blood transfusion in MHD patients for anemia correction might be the risk factor for this high infection rate. Transfusion should be restricted to minimum by the administration of recombinant human erythropoietin in CKD patients to minimize viral infections. No anti-HCV positive patient was found in predialysis group may be for the reason that they had no history of blood transfusion. In our study, high anti-HCV positivity was also significantly associated with duration of maintenance hemodialysis (MHD). Previous studies have also indicated that the duration of dialysis treatment is clearly correlated with $\mathrm{HCV}$ positivity ${ }^{27,7}$. In the present study, the duration of dialysis in $\mathrm{HCV}$ positive patients was higher compared to HCV negative patients.

When biochemical markers associated with viral infections were investigated it was found that serum alanine aminotransferase (ALT) was relatively higher in anti-HCV positive patients. There are reports showing association between ALT and anti-HCV positivity ${ }^{26}$. It has also been shown that the greater the elevation in liver enzymes, higher is the probability of histological evidence of liver disease. Liver biopsy may confirm the presence of active liver disease in these patients.

Hepatitis $\mathrm{C}$ virus infection was high in dialysis patients. Implementing comprehensive infection control program by routine screening of the CKD patients, and proper disinfection and cleaning of hemodialysis units may reduce the infection Rate.

\section{Acknowledgements}

S Sultana, MK Ali, AK Shaha et al

We sincerely acknowledge the help and cooperation of the Immunology Department and CRF project of BIRDEM.

\section{References}

1. Otedo AE, MC Ligeyo SO, Okoth FA, Kayima JK. Seroprevalence of hepatitis B and hepatitis C in maintenance dialysis in a public hospital in a developing country. S Afr Med J 2003; 93: 380-4.

2. Busek SU, Baba EH, Tavares Filho HA, Pimenta L, Salomao A, Correa-Oliveira R, Oliveira GC. Hepatitis C and hepatitis B virus infection in different hemodialysis units in Belo Horizonte, Minas Gerais, Brazil. Mem Inst Oswaldo Cruz 2002; 97: 775-778.

3. Bergman S, Accortt N, Turner A, Glaze J. Hepatitis C infection is acquired pre-ESRD. Am J Kidney Dis 2005; 45: 684-9.

4. Carneiro MA, Martins RM, Teles SA, Silva SA, Lopes CL, Cardoso DD, Vanderborght BO, Yoshida CF. Prevalence and risk factors in hemodialysis patients in Central Brazil: a survey by polymerase chain reaction serological methods. Mem Inst Oswaldo Cruz 2001; 96: 765-769.

5. Fissell RB, Bragg-Gresham JL, Woods JD, Jadoul M, Gillespie B, Hedderwick SA, Rayner HC, Greenwood RN, Akiba T, Young EW. Patterns of hepatitis $\mathrm{C}$ prevalence and seroconversion in hemodialysis units from three continents: the DOPPS. Afr J Med Sci 2002; 31: 311-4.

6. Albuquerque ACCD, Coelho MRCD, Lopes EPA, Lemos MF, Moreira RC Prevalence and risk factors of hepatitis $\mathrm{C}$ virus infection in hemodialysis patients from one center in Recife, Brazil. Mem inst Oswaldo Cruz Rio de Janeiro 2005; 100: 467-70.

7. Mohammad YA, Al-Jiffri, Fadag RB, Ghabrah TM, Ibrahim A. Hepatitis $C$ virus infection among patients on hemodialysis in Jeddah: a single center experience. Saudi J Kidney Dis Transplant 2003; 14: 84-89.

8. Bruguera M, and Jose M, Tapias S. Epidemiology of hepatitis C virus infections. Nephrol Dial Transplant 2000; 15: 12-14.

9. Alter MJ, Favero MS, Moyer LA, Bland LA. National surveillance of dialysis-associated diseases in the United States. ASAIO Trans 1991; 37: 97-109. 
10. Gish RG, Ganado AC. Chronic hepatitis B. Current epidemiology in the Americans and implications for management. J Viral Hepat 2006; 13: 787-798.

11. McNulty CAM, Bowen JK, Williams AJ. Hepatitis $B$ vaccination in predialysis chronic renal failure patients a comparison of two vaccination schedules. Vaccine 2005; 23: 4142-4147.

12. Taheri Sh, Shahidi Sh, Moghtaderi J, Seirafian Sh, Emami A, Eftekhari SM. Response rate to Hepatitis B Vaccination in Patients with Chronic Renal Failure and End-Stage-disease: Influence of Diabetes Mellitus. J Res Med Sci 2005; 10: 384-390.

13. Tong NKC, Beran J, Kee SA, Miguel JL, Sanchez C, Bayas JM, Vilella A, De Juanes JR, Arrazola P, Torrecillas FC, De Novales EL, Hamtiaux V, Lievens M, Stoffel M. Immunogenicity and safety of an adjuvanted hepatitis B vaccine in pre-dialysis and hemodialysis patients. Kidney Int 2005; 68: 2298-2303.

14. Shirin T, Ahmed T, Iqbal A, Islam M, Islam MN Prevalence and risk factors of hepatitis B virus, hepatitis $\mathrm{C}$ virus, and Human Immunodeficiency Virus infections among drug addicts in Bangladesh. J Health Popul Nutr 2000; 18: 145-150.

15. Khan M, Husain M, Yano M. Comparison of seroepidemiology of hepatitis $\mathrm{C}$ in blood donors between Bangladesh and Japan. Gastroenterologia Japonica 1993; 28: 28-31.

16. Ibrahim S, Din SE, Bazzal I, Cairo MBBCH, Egypt. Antibody level after hepatitis B vaccination in hemodialysis patients: Impact of dialysis adequacy, chronic inflammation, local endemicity and nutritional status. J National Med Assoc 2006; 98: 1953-57.

17. Liu YL, Kao MT, Huang CC. A comparison of responsiveness to hepatitis $\mathrm{B}$ vaccination in patients on hemodialysis and peritoneal dialysis. Vaccine 2005; 23: 3957-3967.

18. Taguchi S, Nishioka K, Kawaguchi R, Nakao M, Watanabe I, Migita T. Epidemiological study of hepatitis B and C in 34,336 patients operated at Hiroshima Prefectural Hospital during the period from 1993 to 2000. Mausi 2004; 53: 966-700.
19. Li-Ng M, Tropp S, Danoff A, Bini EJ. Association between Chronic hepatitis B virus infection and diabetes among Asian Americans and pacific Islanders. Dig Liver Dis 2007; 39: 549-56.

20. Saxena Anil K, Panhotra BR. Impact of dedicated space, dialysis equipment, and nursing staff on the transmission of hepatitis $\mathrm{C}$ virus in a hemodialysis unit of the Middle East. Am J Infec cont 2003; 31: 26-33.

21. Qureshi H, Ahsan T, Mujeeb SA, Jawad F, Mehdi I, Ahmed W, Alam SE. Diabetes mellitus is equally frequent in chronic HCV and HBV infection. J Pak Med Assoc 2002; 52: 280-3.

22. Chen HF, Li CY, Chen P, See TT, Lee HY. Seroprevalence of Hepatitis B and C in Type 2 Diabetic Patients. J Chin Med Assoc 2006; 69: 146-152.

23. Rashid HU. 1986-1996: Bangladesh renal registry report. Bangladesh Renal J 2002; 21: 25-28.

24. Islam MN, Hossain RM, Rahman MH, Mansur MA, Hassan MS, Islam MS, Sultana R, Iqbal MM. Hepatitis B (HBV) and C (HCV) among maintenance hemodialysis patients, family members and dialysis staffs. International Society for Hemodialysis 2007; 11: 108.

25. Lopez-Alcorocho JM, Barril G, Ortiz-Movilla N, Traver JA, Bartolom, Eacute J, Sanz P, Selgas R, Carreno V. Prevalence of Hepatitis B, Hepatitis C, GB Virus/ Hepatitis $G$ and TT Viruses in predialysais and hemodialysis patients. J Med Virol 2001; 63:103-107.

26. Sameer O, Huraib. Hepatitis C in dialysis patients. Saudi J Kidney Dis Transplant 2003; 14: 442-450.

27. El-Amin HH, Osmani EM, Mekki MO, Abdelrahem MB , Ismail MO, Yousif M EA, Abbas AM, EIhaj HS, Ammar HK. Hepatitis C virus infection in hemodialysis patients in Sudan: Two centers report. Saudi J Kidney Dis Transplant 2007; 18: 101-106. 